\title{
The Effects of Chemical Composition on Soft Magnetic Materials Behaviour
}

\author{
R. BidulskÝ ${ }^{a}, *$, M. ACtis Grande ${ }^{a}$, L. Ferraris $^{a}$, P. Ferraris ${ }^{a}$ And J. Bidulská ${ }^{b}$ \\ ${ }^{a}$ Politecnico di Torino-Alessandria Campus, V. Teresa Michel 5, 15100 Alessandria, Italy \\ ${ }^{b}$ Faculty of Metallurgy, Technical University of Košice, Letná 9, 04200 Košice, Slovakia
}

\begin{abstract}
The main aim of the presented work was to study the effects of chemical composition on the magnetic properties (in terms of $B-H$ characteristics) of an insulated iron powder compound with various addition of the aluminium alloy $(0,5$ and $10 \mathrm{wt} \%)$. The magnetic properties of the powder were significantly influenced by density and "sintering" effects. The addition of aluminium alloy maintaining suitable values of coercive force, remanence and core losses; this makes the modified insulated iron powder compound a promising soft magnetic material in several applications.
\end{abstract}

PACS numbers: 75.50.-y, 81.20.Ev, 81.40.Rs

\section{Introduction}

The powder metallurgy process provides the ability to manufacture net shape parts from a variety of materials in a cost effective manner. A market segment that can take great advantage of powder metallurgy's (PM) flexibility is the electromagnetic one; examples of PM products that can be used are constituted by powder cores, iron and iron alloys sintered and insulated iron powder compound (IIPC) [1, 2].

IIPC are basically pure iron powder particles coated with a very thin electrically insulated layer. In this case the components made of metal powder cannot be sintered, as it is fundamental that each particle is electrically insulated from the other [3-5].

The main aim of this work is to study the effects of aluminium alloy addition as well as processing conditions on soft magnetic materials (SMM) behaviour in terms of magnetic properties.

\section{Experimental procedures}

The starting material was IIPC with the addition of 0,5 and $10 \mathrm{wt} \%$ aluminium alloy $(\mathrm{Al}-0.95 \% \mathrm{Mg}-0.49 \%$ $\mathrm{Si}-0.21 \% \mathrm{Cu}-0.07 \% \mathrm{Fe}$ ). Powder mixtures were homogenized using a laboratory Turbula mixer for $20 \mathrm{~min}$. Specimens with various green densities were obtained using a $2000 \mathrm{kN}$ hydraulic press, in a disc-shaped mould $(\phi 40 \mathrm{~mm})$ specimens applying a pressure in the range from 400 to $800 \mathrm{MPa}$. Heat treatment was carried out in vacuum furnace at $550^{\circ} \mathrm{C}$ for $30 \mathrm{~min}$. Densities were evaluated using the water displacement method.

\footnotetext{
* corresponding author; e-mail: robert.bidulsky@polito.it
}

\section{Results and discussion}

The material and magnetic properties at $50 \mathrm{~Hz}$ supplied frequency of investigated materials are shown in Table. The magnetic properties of investigated materials appear to be mainly controlled by the density. The remanence and coercivity increased with increasing density that is also attributed to the enhanced densification. However, the subsequent decrease of remanence and increase of coercivity are observed in terms of addition of aluminium alloys. The maximum values of coercivity (about $400 \mathrm{~A} / \mathrm{m}$ ) were attained mainly in case of higher compactive pressures; i.e. a consequence of the higher applied forces that cause a greater reduction of volumes and of present porosities, which typically results in a demagnetization field effect. Two factors are considered with respect to the mentioned results: the magnetic properties of the SMM are mainly influenced by density and "sintering" degree.

The coercivity of the materials with addition of $10 \mathrm{wt} \%$ aluminium alloys was slightly higher than that of other materials. The larger coercivity can be attributed to larger residual stress and demagnetization effect. Nevertheless, since during compaction a stress is introduced in the particles, which deteriorates the soft magnetic properties, a heat treatment has to be settled to provide a stress relief.

Moreover, the addition of $5 \mathrm{wt} \%$ aluminium alloys retained suitable values of coercive force, remanence and core losses with respect of increasing mechanical properties as is presented in reference [6].

Such results seem to be in agreement with the general information obtainable from the technical literature [1-5] and confirm the interest to all the analysed materials. Further studies and optimization of the mixes is required to achieve a suitable combination of mechanical and magnetic performances. 
Material and magnetic properties of investigated material.

TABLE

\begin{tabular}{|c|c|c|c|c|c|}
\hline $\begin{array}{c}\text { Pressure } \\
{[\mathrm{MPa}]}\end{array}$ & Material & $\begin{array}{l}\text { Density } \\
{\left[\mathrm{g} / \mathrm{cm}^{-3}\right]}\end{array}$ & $\begin{array}{c}\text { Core loss } \\
{[\mathrm{W} / \mathrm{kg}]}\end{array}$ & $\begin{array}{c}\text { Remanence } \\
{[\mathrm{T}]}\end{array}$ & $\begin{array}{c}\text { Coercivity } \\
{[\mathrm{A} / \mathrm{m}]}\end{array}$ \\
\hline 400 & IIPC & 6.97 & 11.30 & 0.021 & 184 \\
\hline 600 & IIPC & 7.39 & 8.3 & 0.027 & 205 \\
\hline 800 & IIPC & 7.47 & 9.85 & 0.023 & 218 \\
\hline 400 & $\begin{array}{c}\text { IIPC }+ \\
5 \mathrm{wt} \% \mathrm{Al} \text { alloys }\end{array}$ & 6.36 & 15.60 & 0.007 & 196 \\
\hline 600 & $\begin{array}{c}\text { IIPC }+ \\
5 \mathrm{wt} \% \mathrm{Al} \text { alloys }\end{array}$ & 6.52 & 14.80 & 0.012 & 220 \\
\hline 800 & $\begin{array}{c}\text { IIPC }+ \\
5 \mathrm{wt} \% \mathrm{Al} \text { alloys }\end{array}$ & 6.66 & 25.30 & 0.023 & 312 \\
\hline 400 & $\begin{array}{c}\text { IIPC }+ \\
10 \mathrm{wt} \% \mathrm{Al} \text { alloys }\end{array}$ & 5.77 & 50.00 & 0.005 & 227 \\
\hline 600 & $\begin{array}{c}\text { IIPC }+ \\
10 \text { wt } \% \mathrm{Al} \text { alloys }\end{array}$ & 5.85 & 54.50 & 0.006 & 310 \\
\hline 800 & $\begin{array}{c}\text { IIPC }+ \\
10 \mathrm{wt} \% \mathrm{Al} \text { alloys }\end{array}$ & 5.9 & 34.20 & 0.010 & 331 \\
\hline
\end{tabular}

\section{Conclusions}

1. The magnetic properties of the powder were significantly influenced by density and "sintering" effect.

2. The addition of aluminium alloys in $5 \mathrm{wt} \%$ is beneficial obtaining a suitable value of coercive force under $200 \mathrm{~A} / \mathrm{m}$; as well as values of core losses and remanences in $15.6 \mathrm{~W} / \mathrm{kg}$ and $0.007 \mathrm{~T}$, respectively.

3. The addition of aluminium alloys in $10 \mathrm{wt} \%$ is crucial due to larger residual stress and demagnetization effect.

\section{Acknowledgments}

R. Bidulský thanks the Politecnico di Torino and the Regione Piemonte for co-funding by the fellowship. J. Bidulská thanks the bilateral project SK-PL-0011-09.

\section{References}

[1] F.G. Hanejko, C. Oliver, H.G. Rutz, in: Advances in Powder Metallurgy and Particulate Materials, Vol. 6, MPIF, Princeton (NJ) 1992, p. 375.

[2] Ch.G. Oliver, IEEE Trans. Magn. 31, 3982 (1995).

[3] M. Actis Grande, A. Boglietti, A. Cavagnino, L. Ferraris, P. Ferraris, in: IECON, Industrial Electronics Conference, Porto 2009, IEEE Industrial Electronics Society, 2009, p. 1130, DOI: 10.1109/IECON.2009.5414683.

[4] L. Hultman, O. Andersson, A. Jack, SAE Trans. 112, 158 (2003).

[5] I. Gilbert, S. Bull, T. Evans, A. Jack, D. Stephenson, A. de Sa, J. Mater. Sci. 39, 457 (2004).

[6] R. Bidulský, M. Actis Grande, L. Ferraris, J. Bidulská, J. Optoelectron. Adv. Mater. 12, 1356 (2010). 